УДК 80:811.11

DOI https://doi.org/10.26661/2414-1135-2021-81-2-33

\title{
РОЛЬ ПОЗАМОВНИХ ЧИННИКІВ У ФОРМУВАННІ І ФУНКЦІОНУВАННІ ТЕРМІНІВ (НА МАТЕРІАЛІ АНГЛІЙСЬКИХ ТЕРМІНІВ КОСМЕТОЛОГІЇ ТА ЕСТЕТИЧНОї МЕДИЦИНИ)
}

\author{
Шундікова I. I. \\ кандидат філологічних наук, \\ асистент кафедри романо-германської філологіі \\ Тернопільський національний педагогічний університет імені Володимира Гнатюка \\ вул. М. Кривоноса, 2, Тернопіль, Україна \\ orcid.org/0000-0001-7139-1449 \\ i.boiko.online@gmail.com
}

\begin{abstract}
Ключові слова: термін, термінологія косметологіі та естетичної медицини, сочіотермінознавство, позамовні чинники, рекламний текст.
\end{abstract}

\begin{abstract}
Функціонування термінів у різних професійних сферах привертає увагу не лише лінгвістів, а й представників суспільних наук. Такий інтерес зумовлений тим, що мова - це соціальне явище, а термін безпосередньо пов'язаний із професійними чинниками та виконує роль засобу інформаційного обміну. Одним із яскравих прикладів експліцитного впливу суспільства на функціонування термінів може слугувати англомовна термінологія косметологіїта естетичної медицини,понятійний апарат якої зараз активно розвивається в унісон із науковим прогресом, глобалізацією економіки, розширенням культурних зв'язків, мобільністю населення та поширеністю мультилінгвізму. До зовнішніх чинників впливу, які зумовили еволюцію фахової мови галузей косметології та естетичної медицини, належать соціоекономічні, соціокомунікативні, соціоісторичні та соціопсихологічні чинники. Мета статті - розглянути вплив соціальних змін на семантичні та функціональні особливості англійських термінів зазначених галузей, які вжито в рекламних текстах, а також окреслити їхній внесок у формування провідних цінностей сучасного глобалізованого суспільства. Дослідження виконане в межах напряму соціотермінознавства, актуальність якого полягає в розкритті й урахуванні впливу позамовних чинників на розвиток терміносистем. Проведений аналіз показав, що термінологія косметології та естетичної медицини, з одного боку, зазнає впливу суспільних змін, що виявляється крізь семантичні процеси метафоризації, поширення термінів-англіцизмів в інші мови та запозичення і термінологізацію іншомовної лексики. із другого боку, терміни, що функціонують $\mathrm{i}$ взаємодіють з іншими лексичними одиницями в рекламних контекстах, беруть участь у насадженні таких атрибутів сучасного глобалізованого суспільства, як індивідуалізм, толерантність, споживацька свідомість, соціальна самоідентифікація за допомогою торгових брендів, гендерна уніфікація. Отже, результати здійсненої розвідки підтверджують взаємодію і взаємовплив соціальних чинників та особливостей мовного функціонування.
\end{abstract}




\title{
THE ROLE OF EXTRALINGUISTIC FACTORS IN THE FORMATION AND FUNCTIONING OF TERMS (BASED ON THE ENGLISH TERMINOLOGY OF COSMETOLOGY AND AESTHETIC MEDICINE)
}

\author{
Shundikova I. I. \\ Candidate of Philological Sciences, \\ Assistant at the Department of Romance and Germanic Philology \\ Ternopil Volodymyr Hnatiuk National Pedagogical University \\ M. Kryvonosa str., 2, Ternopil, Ukraine \\ orcid.org/0000-0001-7139-1449 \\ i.boiko.online@gmail.com
}

\begin{abstract}
Key words: term, terminology of cosmetology and aesthetic medicine, socioterminology, extralinguistic factors, advertising text.
\end{abstract}

\begin{abstract}
Functioning of terms in various professional fields attracts the attention not only of linguists but also of the representatives of social sciences. This interest arises from two facts: language is a social phenomenon, and terms are linked to professional communication and serve as a means of information exchange. One striking example of the explicit influence of society on the functioning of terms is the English terminology of cosmetology and aesthetic medicine. Its conceptual apparatus is now actively developing in unison with scientific progress, globalization, economic expansion, cultural mobility, and the prevalence of multilingualism. Socio-economic, socio-communicative, sociohistorical and socio-psychological factors are external sources of influence that have led to the evolution of professional language of cosmetology and aesthetic medicine. The purpose of the article is to consider the impact of social change on the semantic and functional features of English terms of these industries, used in advertising texts, as well as to outline their contribution to the formation of prominent values of modern globalized society. The study was performed within the field of socioterminology, the relevance of which is determined by the intention to disclose the impact of extralinguistic factors on the development of terms. The analysis has shown that terminology of cosmetology and aesthetic medicine, on the one hand, is affected by social changes, manifested through semantic processes of metaphorization, the spread of English terms in other languages and borrowings. On the other hand, the terms, which function and interact with other lexemes in advertising contexts, participate in the dissemination of such attributes of modern globalized society as individualism, tolerance, consumerism, self-identification through brands, and gender unification. The results of the study confirm the mutual influence of social factors and functional features of language.
\end{abstract}

Вступ. Функціонування термінів у різних професійних сферах привертає увагу не лише лінгвістів, а й представників суспільних наук. Такий інтерес зумовлений тим, що мова - це соціальне явище, а термін безпосередньо пов'язаний із професійними чинниками та виконує роль засобу інформаційного обміну.

На соціокомунікативну сутність термінів вказують багато дослідників. Так, на думку Т. Кабре, фахові знаннєві одиниці, зокрема терміни, є мультивимірними, містять когнітивний, лінгвістичний i соціокомунікативний компоненти $[1$, с. 17], що закономірно можуть ставати об'єктами окремого аналізу. Ф. Годін вказує на доцільність вивчення соціального аспекту термінів і зазначає, що використання соціолінгвістичних принципів у дослі- дженні термінологічних варіацій у різноманітних контекстах дозволяє виявити рівень знань, фаховий та соціальний статус і стосунки співрозмовників [3]. Популярним також став аналіз термінних одиниць у дискурсі та розгляд соціокомунікативних і дискурсивних умов, що спричиняють появу різних типів текстів [2, с. 51]. На необхідність дослідження термінів на основі синтезу суспільних та лінгвістичних чинників наголошує і Р. Кобрін, адже за допомогою терміна відбувається рух інформації як важливого чинника функціонування і розвитку суспільства. Під час формування нової наукової галузі утворюється їі термінологія, яка чуттєва до зовнішнього впливу i, як наслідок, у ній виразно розкривається вплив суспільства на мову [4, с. 209]. 
Одним із яскравих прикладів експліцитного впливу суспільних чинників на функціонування термінів може слугувати англомовна термінологія косметології та естетичної медицини (далі - КЕМ), понятійний апарат якої зараз активно розвивається в унісон із науковим прогресом, глобалізацією економіки, розширенням культурних зв'язків, мобільністю населення та поширеністю мультилінгвізму. Водночас можна припустити, що соціальні чинники не лише формують особливості функціонування термінів, а і зазнають зворотного тиску, оскільки «мова відіграє центральну роль у впливі на наші реалії» [7, с. 222]. Отже, мета дослідження, запропонованого в цій статті, - розглянути вплив суспільних змін на семантичні та функціональні особливості англійських термінів галузей КЕМ, які вжито в рекламних текстах, а також окреслити їхній внесок у формування провідних тенденцій сучасного глобалізованого суспільства. Дослідження виконане в межах напряму соціотермінознавства, яке «застосовує соціолінгвістичні принципи до теорії термінології й розглядає термінологічні варіації на фоні різних контекстів вжитку» [2, с. 51]. Актуальність соціотермінознавчого підходу полягає в розкритті й урахуванні впливу позамовних чинників на розвиток терміносистем, що дає змогу глибше зрозуміти сутнісні процеси, що відбуваються в них.

Предметом розвідки є семантичні та функціональні особливості термінів КЕМ в англійських рекламних текстах, зумовлені сучасними соціокомунікативними процесами, та роль зазначених термінів у формуванні провідних цінностей глобалізованого суспільства. Об'скт дослідження терміни КЕМ, що функціонують у 12 рекламних текстах, вилучених 3 англомовних журналів (Cosmopolitan, FFM, Esquire, Girls'Life), які опубліковано у 2015-2020 pp.

Виклад основного матеріалу дослідження. КЕМ належать саме до тих галузей, які нерозривно поєднані 3 розвитком суспільства. Вони беруть свій початок із глибини віків, синтезують основні досягнення минулого і сучасного. Новітні галузі КЕМ розвиваються зі зростанням життєвого рівня населення і суспільних потреб у цій сфері, пов'язаних із тим, що в сучасному світі роль зовнішнього вигляду людини стає надзвичайно важливою. Соціокультурні чинники нині формують образ ідеальної зовнішності, який асоціюється 3 певними стандартами поведінки, благополуччям, успішністю, заможністю, а усунення різноманітних дефектів або ознак старіння стало складовими частинами сучасного життя. Наприклад, під час проведення соціально-психологічних досліджень щодо ставлення особистості до зовнішності популярними виявилися трактування зовнішності в осіб, залежних від косметичних процедур, та роль макіяжу в оцінці привабливості [5, с. 69].
До зовнішніх чинників впливу, які зумовили еволюцію фахової підсистеми галузей КЕМ, належать: соціально-економічні (використання досягнень минулих поколінь у різних галузях, сучасні маркетингові ходи, використання інноваційних технологій у сфері медицини, косметології, фармацевтиці, дієтології); соціально-комунікативні (реклама, використання штучного інтелекту - «віртуальні примірочні», 3D-макіяж, «розумний догляд за обличчям», освітні програми від брендів, майстер-класи); соціально-історичні (міграційні процеси, мультилінгвізм, поширення певної ментальності); соціально-психологічні (вплив на людину спілкування, навчання, виховання, суспільства тощо).

Суспільні зрушення змінюють мовний простір, який стає високотермінологізованим. Терміни $є$ лінгвістичною реалізацією понять, які змінюються відповідно до розвитку суспільства, що відбивається на їхніх лексичних значеннях. Як зазначає Т. Лєбєдєва, особливістю мови як суспільного явища $є$ те, що суспільство створює мову, контролює іiі та закріплює в системі комунікативних засобів, які відповідають його потребам [8]. За М. Кочерганом, соціальність мови полягає в іiі використанні для обслуговування всіх сфер життя, 3 можливістю відображати суспільну свідомість (крізь ідеологію, мистецтво та науку). Підтвердженням цього є наявність базових функцій мови: комунікативної (мова як засіб спілкування) та когнітивної (мова як засіб мислення і пізнання) [9].

Комунікація, таким чином, є суспільним явищем 3 огляду на її виникнення, сутність та умови розвитку [9, с. 5]. Необхідність у комунікації, передусім вербальній, зумовлена суспільним способом буття людини. Мінливість мови є результатом її головної функції - бути засобом комунікації, а здатність мови до модифікацій дає їй змогу не відокремлюватися від процесів перебудови позамовної реальності та пристосовуватись до швидкої зміни навколишнього середовища [10, с. 76].

Відомо, що текст є основною одиницею комунікації, універсальним засобом для використання в різних комунікативних системах. Будь-який текст потрібно розглядати як «складне мовленнєве утворення, всесторонньо визначене об'єктивним призначенням i функціонуванням в акті мовленнєвої комунікації, де мова віднаходить колективно найбільш значущу форму свого прояву» [12]. Текст несе інформацію та відповідні ій ситуативні мотивації, отже, є засобом впливу на різноманітні соціальні групи (наприклад, за віком, національністю, гендерними ознаками тощо).

Зростання комунікативних потреб суспільства відповідно до вимог часу викликає неминучі зміни, які відбуваються в різних сферах життя. Їхній вплив можна виявити, якщо провести аналіз 
термінів КЕМ у відповідних жанрах і контекстах (як-от реклама, презентація, контакти з покупцем, каталоги продукції, програми підсилення лояльності покупців до бренду, вебсайти, PR-заходи тощо). Отже, далі простежимо, як суспільні зміни відображаються в лінгвальних модифікаціях термінів у рекламних текстах.

Інтенсивний розвиток та поява нових професійних і наукових галузей стимулюють перехід слів щоденного вжитку у спеціальну лексику, зокрема термінологію. Наприклад, у рекламі популярного косметичного засобу спостерігаємо процес семантичної зміни через метафоризацію. Загальновживане слово використовується тут у новітньому значенні, утворює нове професійне поняття: 4d Target technology based on oxygen drones providing a targeted effect on skin cells. Як відомо, первинна семантика слова target - «ціль». У контексті косметичної реклами в нього розвинулось нове значення - «таргетований, спрямований на досягнення конкретної мети за допомогою косметичного засобу». Під час семантичної зміни вихідне значення виразу $4 d$ («чотири виміри») у поєднанні 3 target метафорично переосмислюється як «цілеспрямований ефект у чотирьох вимірах» (пов'язаний із сучасними технологіями в косметології), що дозволяє привернути увагу споживача та наголосити на сучасності розробки. Те саме стосується і слова dron, яке позначає військове термінологічне поняття зі значенням «пошуковий пристрій»; у сфері косметології воно набуло так само термінологічного, але цілком іншого значення - «інгредієнт косметичного засобу, що знаходить клітини шкіри, яким необхідні певні елементи, і постачає їх».

Розглянемо ще один приклад, цього разу термін booster: Due to boosters fluid texture they are like serums but taken to their maximum. Boosters achieve a faster, longer-lasting effect than any other cosmetics, working like intensive recoverers. Вихідне значення лексичної одиниці boost - «прискорювати, посилювати, спричиняти до інтенсивнішого, сильнішого прояву якого-небудь стану, процесу, особливості, якості». У контексті рекламного оголошення в галузях КЕМ вона метафорично переосмислюється як «підсилювач ефективності біологічно активних речовин, що входять до косметичних засобів i, як наслідок, досягнення більш високого, бажаного косметичного ефекту на шкіру».

Вплив на англомовну термінологію КЕМ опосередковано чинять сучасні міграційні процеси, що призводять до утворення нового соціокультурного простору. Люди зберігають власну ідентичність і водночас інтегруються в іншу соціокультурну площину, де взаємодіють групи, різні за соціальним статусом, рівнем доходу, освіти, національністю тощо. Процес інтернаціоналіза- ції мови можна спостерігати на прикладі терміна makeup (Make your own make up or buy organic and/ or natural makeup products from trusted companies), який широко застосовується в рекламі косметичних засобів у всьому світі (зокрема, в Україні кирилицею - мейкаn) і не потребує додаткового перекладу або пояснення.

Оскільки зосередження високорозвинутих технологій відбувається в регіонах, де домінує англійська мова, іiї вплив на інші мови є неминучим. Це особливо помітно на прикладі англійських термінів КЕМ, деякі з яких почали вживатися в інших мовах, як це можна побачити на прикладі косметичної реклами іспанською мовою: Peeling exfoliante e hidratant con células madre vegetales para cara y cuerpo; acción lifting mirada despierta Conseguirás, de inmediato una piel renovada, extraordinariamente luminosa y conun espectacular efecto lifting; láser/laser - Alivio de cualquier sensación de la piel después de tratamientos láser, depilación [12]. У цьому фрагменті використано терміни-англіцизми peeling, lifting, laser, які, очевидно, уже не потребують експлікації.

Мова - це динамічний феномен, який існує лише у практиці комунікації, відображає мінливість навколишнього життя, що, зокрема, маніфестується під час використання іншомовних слів-термінів в англійській мові. В англомовних рекламних текстах галузей КЕМ активно вживаються чимало слів 3 інших мов - chok chok (з корейської), shampoo (з хінді), carnauba wax (3 португальської), Jojoba oil (3 іспанської),

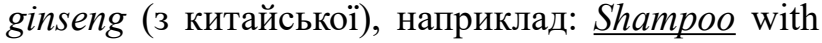
ginseng can prevent or stop your hair loss. Хоча в їхній семантиці частково зберігається національно-культурний значеннєвий компонент, який відображає специфічні риси матеріальної та духовної культури певного лінгвокультурного соціуму $[6$, с. 9], він не заважає успішній асиміляції та термінологізації таких слів. Наведені приклади зайвий раз підтверджують, що англійська мова, зокрема іiі термінологічні шари, адаптується до соціальних змін та співіснує з іншими мовами [7].

Гаслом косметичних компаній нині $\epsilon$ «кожен - індивідуальний», оскільки покупці прагнуть більш персоналізованих продуктів, які б точно відповідали їхнім потребам. Отже, мова КЕМ стає більш семантично розмаїтою. Наприклад, раніше ринок тональних основ починався 3 базових відтінків (white, fair, beige, medium), а косметичні фірми переважно орієнтувалися лише на відтінки для споживачів зі світлою шкірою, тоді як ситуація для темношкірих клієнтів була менш сприятливою. Сьогодні популярні всі відтінки - від найсвітліших до найтемніших; їх вербально представлено в кольоровому ряді, що позначає більше п'ятдесяти відтінків, виражених 
англійськими колоративними лексемами, серед яких, наприклад, black opal, toffee tease, teddy або chocolate. Уживання таких лексем поруч із термінами КЕМ свідчить про більшу увагу і толерантність до людей різних національностей, що стало важливою ознакою сучасності.

Використання термінів КЕМ у рекламних текстах - цьому інструменті формування соціальних правил (моди, норм поведінки, моралі) - підтримує формування масової споживацької свідомості, характерної для нинішньої епохи консумеризму. Розглянемо такий приклад: Face masks are one of the hottest "au courant" beauty trends right now. They're everywhere - a result of the Korean beauty phenomenon that's sweeping the internet this summer. A popular question is how often should you use a face mask? In fact, Korean women talk about using face masks several times a week because of the way these masks leave their skin glowing, fresh, and radiant. У цьому фрагменті поєднання емоційно забарвленої лексики (the hottest "au courant", Korean beauty phenomenon, glowing, fresh, radiant) 3 повторюваним терміном face mask чинить прямий комунікативний тиск на адресата, примушує його повірити в унікальність рекламованого продукту, його купити. Як наслідок, термін face mask набуває експліцитних меліоративних конотацій і перетворюється в масовій свідомості на позначення важливого атрибута життя сучасної жінки.

Варто зазначити, що в рекламі брендових косметичних продуктів від самого початку закладена певна соціальна спрямованість. Купуючи продукцію відомих брендів, споживач намагається ідентифікувати себе поміж оточуючення, символічно залучається до певного стилю життя і наближається до бажаного соціального статусу. На вербальному рівні цьому сприяе постійне використання термінів КЕМ, які мають позитивні конотації, поруч із назвою бренду, наприклад: Estee Lauder focuses on combining natural ingredients to make corrective cosmetics and skincare for men. Такі контекстуальні особливості функціонування термінів сприяють фіксації брендів у масовій свідомості, формуванню позитивного ставлення до них.

Терміни КЕМ також беруть участь у здійсненні соціально-психологічного впливу на цільові групи (молодіжні, дитячі, підліткові, чоловічі, жіночі), водночас відображають і формують сучасні тенденції щодо соціальної ідентифікації таких груп. Розглянемо уривок із тексту, що рекламує засоби догляду для чоловіків: Get your handsomest face ever with the latest on men's skin care from GQ, including shaving tips, expert grooming advice and all our editors' recommended skin care products like moisturizer, shaving cream, anti-aging, and more. Значна частина вжитих тут термінів (skin care, shaving tips, grooming, skin care products, moisturizer, shaving cream, anti-aging) позначають універсальні поняття та продукти, якими послуговуються представники різних статей, тим самим навіюють ідею гендерної уніфікації. Цікаво, що диференціація цього тексту як зорієнтованого на чоловіків відбувається на основі не термінологічної, а загальновживаної лексики (handsomest, men's) із семантикою, що вказує на чоловічу стать.

Висновки і перспективи подальших розробок. Отже, можна підсумувати, що термінологія КЕМ, з одного боку, зазнає впливу суспільних змін, що виявляється крізь семантичні процеси метафоризації, поширення термінів-англіцизмів в інші мови та, навпаки, запозичення і термінологізацію іншомовної лексики. Із другого - терміни КЕМ, що функціонують у рекламних контекстах, беруть участь у взаємодії з іншими лексичними одиницями, у насадженні таких атрибутів сучасного глобалізованого суспільства, як індивідуалізм, толерантність, споживацька свідомість, соціальна самоідентифікація за допомогою торгових брендів, гендерна уніфікація. Результати здійсненої розвідки підтверджують взаємодію і взаємовплив соціальних чинників і особливостей мовного функціонування. Перспективу подальших досліджень убачаємо в застосуванні соціолінгвістичних принципів до розгляду еволюції термінології КЕМ від стародавніх часів до наших днів.

\section{ЛІТЕРАТУРА}

1. Cabré Castellví M.T. Theories of terminology: their description, prescription and explanation. Terminology. 2003. № 9 (2). S. 163-199. DOI: 10.1075/term.9.2.03cab.

2. Гуменюк Т. Сучасні лінгвістичні теорії в термінознавстві. Science and Educationa New Dimension. Philology. 2014. II (7). Iss. 34. URL: www.seanewdim.com.

3. Gaudin F. Pour une socioterminologie. Des problèmes sémantiques aux pratiques institutionnelles. Coll. Publications de l'Université de Rouen. Rouen, Université de Rouen, 1993. № $182.255 \mathrm{p}$.

4. Кобрин Р. Современная научно-техническая революция и ее влияние на развитие языка. Онтология языка как общественного явления. Москва, 1983. С. 208-266.

5. Даниленко Н., Меднікова Г. Проблема ставлення особистості до власної зовнішності в психологічній науці. Вісник Харківського національного педагогічного університету імені Г.С. Сковороди. Серія «Психологія». 2017. Вип. 57.C.67-77.URL: http://nbuv.gov.ua/ UJRN/VKhnpu_psykhol_2017_57_8. DOI.org/ 10.5281/zenodo.1184262. 
6. Яхонтова Т. Жанрообразующая лексика английского неоромантического экзотико-приключенческого романа : автореф. дис. ... канд. филол. наук. Львов, 1991. 16 с.

7. Martin J.N., Thomas K. Nakayama. Intercultural Communication in Contexts. 5'th ed. Boston, MA : McGraw-Hill, 2010. P. 222-224.

8. Лєбєдєва Т. Динаміка розвитку військової лексичної підсистеми в сучасній німецькій мові : дис. ... канд. філол. наук: 10.02.04. Київ, 2002. 233 c.

9. Кочерган М. Загальне мовознавство: підручник для студентів філологічних спеціальностей вищих закладів освіти. Київ : Видавничий центр «Академія», 1999. 288 с.

10. Каменская О. Текст и коммуникация. Москва, 1990. C. 3-14.

11. Бехта I. Види текстової комунікації. Вісник Львівського університету. Серія «Міжнародні відносини». 2001. URL: https://www. academia.edu/29443426/\%D0\%92\%D0\%98\% D0\%94\%D0\%98 \%D0\%A2\%D0\%95\%D0\%9 A $\%$ D0\%A $1 \%$ D0\%A2\%D0\%9E\%D0\%92\%D0 $\% 9 \mathrm{E} \% \mathrm{D} 0 \% 87 \% \mathrm{D} 0 \% 9 \mathrm{~A} \% \mathrm{D} 0 \% 9 \mathrm{E} \% \mathrm{D} 0 \% 9 \mathrm{C} \%$ D0\%A3\%D0\%9D\%D0\%86\%D0\%9A\%D0\%9 $0 \% \mathrm{D} 0 \% \mathrm{~A} 6 \% \mathrm{D} 0 \% 86 \% \mathrm{D} 0 \% 87$.

12. Martínez Tejedor Cristina, de Henares de Alcalá Universidad. The influence of the English language on the description of cosmetic products. Alicante Journal of English Studies. 2017. № 30. P. 308-334. DOI: 10.14198/raei.2017.30.11.

\section{REFERENCES}

1. Cabré Castellví M.T. (2003) Theories of terminology: their description, prescription and explanation. Terminology, № 9 (2), S. 163-199. DOI: https://doi.org/10.1075/term.9.2.03cab.

2. Humeniuk T.I. (2014) Suchasni linghvistychni teoriji v terminoznavstvi [Modern linguistic theories of terminology]. Science and Education a New Dimension (electronic journal), Philology, II (7), Issue: 34 . Retrieved from:ttps://seanewdim.com/ uploads/3/4/5/1/34511564/.

3. Gaudin F. (1993) Pour une socioterminologie. Des problèmes sémantiques aux pratiques institutionnelles.Coll. Publications de l'Université de Rouen, № 182, Rouen, Université de Rouen, 255 p.

4. Kobrin R.G. (1983) Sovremennaya nauchno-tehnicheskaya revolyutsiya i ee vliyanie na razvitie yazyika [The modern scientific and technological revolution and its impact on the development of the language]. V kn.: Ontologiya yazyika kak obschestvennogo yavleniya [Ontology of language as a social phenomenon] Moskva, pp. 208-266.

5. Danylenko N.M., Mednikova H.I. (2017) Problema stavlennia osobystosti do vlasnoi zovnishnosti $\mathrm{v}$ psykholohichnii nautsi [Problem persons attitude to their own physical appearance in psychological science] Visnyk Kharkivskoho natsionalnoho pedahohichnoho universytetu imeni H.S. Skovorody. Psykholohiia, Vyp. 57, S. 67-77. URL: http://nbuv.gov.ua/ UJRN/VKhnpu_psykhol_2017_57_8Doi. org/10.5281/zenodo.1184262.

6. Yakhontova T.V. (1991) Zhanroobrazuyushchaya leksika angliyskogo neoromanticheskogo ekzotiko-prikliuchencheskogo romana [Genre-forming vocabulary of the English neoromantic exotic adventure novel]. (PhD Thesis), Lviv: Ivan Franko National University of Lviv.

7. Martin J.N., Nakayama Thomas K. (2010) Intercultural Communication in Contexts. 5th ed., Boston, MA: McGraw-Hill, Pp. 222-224.

8. Liebiedieva T.B. (2002) Dynamika rozvytku viiskovoi leksychnoi pidsystemy v suchasnii nimetskii movi [Dynamics of development of the military lexical subsystem in modern German]: ( $\mathrm{PhD}$ Thesis), Kyiv: National Linguistic University.

9. Kocherhan M.P. (1999) Zahalne movoznavstvo: pidruchnyk dlia studentiv filolohichnykh spetsialnostei vyshchykh [Linguistics: a textbook for students of philological specialties of higher education institutions] Kyiv, Vydavnychyi tsentr "Akademiia".

10. Kamenskaya O. L. (1990) Tekst i kommunikatsiya. [Text and communication] Moskva.

11. Bekhta I. (2001) Vydy tekstovoi komunikatsii [Types of text communication]. Visnyk Lvivskoho universytetu. Seriia "Mizhnarodni vidnosyny" [Bulletin of Lviv University. International Relations Series.] (electronic journal) https://www.academia.edu/29443426

12. Martínez Tejedor, Cristina de Henares de Alcalá, Universidad. (2017) The influence of the English language on the description of cosmetic products. Alicante Journal of English Studies, 30, Pp. 308-334. DOI: 10.14198/raei.2017.30.11 